\section{ПPABO}

УДК 347.93

\section{СРОКИ ОБРАЩЕНИЯ В СУД: ПРЕПЯТСТВИЯ К ЗАЩИТЕ ПРАВ РАБОТНИКА ИЛИ СПОСОБ БОРЬБЫ СО ЗЛОУПОТРЕБЛЕНИЕМ ПРАВОМ}

\section{О. Н. Куренкова}

кандидат юридических наук,

доцент кафедры конституционного и муниципального права,

Саратовский государственный университет

E-mail: olga-git64@mail.ru

Введение. Статья посвящена актуальной и важной для современной России проблеме сокращенных сроков обращения за защитой трудовых прав работников. Цель. Основная цель работы состоит в анализе практических ситуаций, когда сокращенные сроки препятствовали работникам в защите их прав и ситуаций, когда работники злоупотребляли своим правом обратиться в суд и делали это в последний день установленного срока. Также целью работы является анализ проблем защиты прав работников надзорными органами с учетом судебной практики расширительного толкования сроков обращения в суд. Результаты. Автором последовательно рассмотрены различные практические ситуации применения сокращенных сроков обращения в суд для работников с использованием формально-логического метода в результате изучения практики работы Гострудинспекции и судов Саратовской области; исследованы данные ситуации и сделаны определенные выводы по защите прав работников. Кроме этого, сделан вывод о необходимости совершенствования трудового законодательства. Выводы. Автор делает выводы о состоянии надзорной политики и о позитивной роли как судебной, так и досудебной защиты прав работников. В работе также подчеркивается достаточность и эффективность полномочий, закрепленных в рамках института надзора за соблюдением законодательства о труде. При этом в реализации надзорных полномочий Гострудинспекций особая роль отводится защите нарушенных трудовых прав конкретных работников по их обращениям, что подчеркивает ее значение как самостоятельного многоаспектного вида надзорной деятельности Федеральной службы по труду и занятости.

Ключевые слова: законодательство о труде, Трудовой кодекс, сроки обращения в суд, Гострудинспекция.

\section{Введение}

Российская Федерация как социальное государство стремится обеспечивать достойную жизнь своим гражданам, в том числе посредством защиты и восстановления нарушенных или оспоренных прав. Работник в соответствии с ч. 1 ст. 392 Трудового кодекса Российской Федерации имеет право обратиться в суд за разрешением индивидуального трудового спора в течение трех месяцев со дня, когда он узнал или должен был узнать о нарушении своего права, а по спорам об увольнении - в течение одного месяца со дня вручения ему копии приказа об увольнении либо со дня выдачи трудовой книжки [1].

Такими короткими сроками государство побуждает работников к защите трудовых прав, стремлению быстро восстановить нарушенные права. Ведь трудовые отношения очень динамичны, поэтому
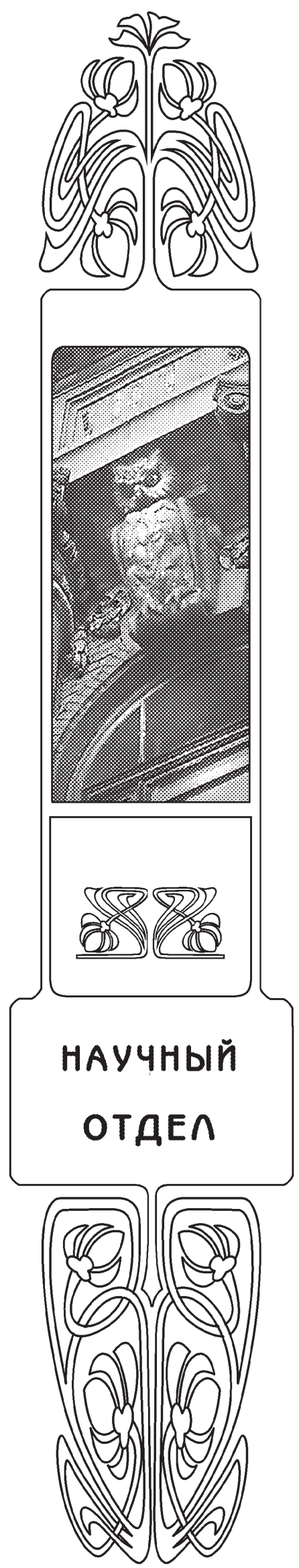
применение сроков, установленных для гражданских правоотношений, невозможно, так как некоторые кадровые документы хранятся всего 1 год, либо к моменту рассмотрения дела в суде уволятся те, кто мог бы подтвердить юридически значимые обстоятельства.

\section{Цель}

Основная цель работы состоит в анализе практических и правовых факторов, детерминирующих развитие участия судебных и надзорных органов в проведении защиты трудовых прав работников и исследовании сокращенных сроков обращения за защитой права на труд как самостоятельной правовой категории.

\section{Результаты}

У работника есть право обратиться с письменным заявлением о нарушении его прав, в том числе незаконном увольнении или невыплате заработной платы, в Гострудинспекцию или в прокуратуру. Однако действующим законодательством не предусмотрены сроки для обращения работника в контролирующие и надзорные органы. А в соответствии с положениями Федерального закона от 02 мая 2006 г. № 59-Ф3 государственные органы рассматривают обращения граждан не позднее 30 дней со дня их регистрации, в крайнем случае - в течение 60 дней [2].

Таким образом, если работник обратится с заявлением о незаконном увольнении в прокуратуру в течение недели после увольнения, то, скорее всего, до истечения месячного срока, если решит дождаться окончательного разрешения своих требований, он не успеет подать заявление в суд, даже в том случае, если обращение будет рассмотрено по существу, а не перенаправлено в Гострудинспекцию.

Так, работник С. обратился в Гострудинспекцию в Саратовской области с заявлением о незаконном увольнении из ООО «У» через 10 дней после увольнения. В течение трех дней, установленных ч. 2 ст. 8 Федерального закона от 02 мая 2006 г. № 59-Ф3 (ред. от 07 мая 2013 г.) «О порядке рассмотрения обращений граждан Российской Федерации» [2], обращение было зарегистрировано и передано должностному лицу для рассмотрения по существу. В течение 30 дней была проведена проверка соблюдения работодателем законодательства о труде, выявлены грубые нарушения порядка увольнения, работодателю выдано обязательное для исполнения предписание, виновное лицо привлечено к административной ответственности, заявителю направлен письменный ответ.
Однако государственный инспектор труда, выдав предписание на 21-й день рассмотрения обращения Гострудинспекцией, не уложился в месячный срок, установленный ч. 1 ст. 392 Трудового кодекса РФ для обращения в суд. В результате предписание государственного инспектора труда было отменено судом по жалобе работодателя, поскольку выдача обязательного для исполнения предписания об устранении нарушений трудового законодательства в отношении конкретного работника связана с вмешательством государства в фактически возникший между этим работником и работодателем трудовой спор (не урегулированные разногласия по вопросам применения трудового права).

Такое вмешательство со стороны государства оправданно необходимостью осуществления надзора за соблюдением трудового законодательства и защитой прав работника как наименее защищенной стороны трудовых отношений. Вместе с тем вмешательство должно быть соразмерным и выдача предписания не должна нарушать справедливого баланса законных интересов работника и работодателя.

Выдача предписания, возлагающего на работодателя обязанность устранить нарушение трудового законодательства в отношении конкретного работника, за пределами сроков, предусмотренных ч. 1 ст. 392 Трудового кодекса РФ, в течение которых работник имел право требовать судебной защиты нарушенных прав, неизбежно приводит к нарушению справедливого баланса интересов сторон трудового спора.

Если работник подаст иск в суд после обращения в надзорные органы, то, возможно, в удовлетворении заявленных требований откажут и пропущенный срок восстановлен не будет, поскольку в соответствии с Постановлением Пленума Верховного Суда РФ от 17 марта 2004 г. № 2 предварительное рассмотрение обращений граждан во внесудебных органах не относится к числу уважительных причин пропуска срока [3].

В то же время, если работник, не обращаясь ни в Гострудинспекцию, ни в прокуратуру, по истечении установленных ч. 1 ст. 392 Трудового кодекса РФ сроков подаст исковое заявление в суд, то при наличии уважительных причин пропуска срока, несмотря на ходатайство ответчика о применении последствий пропуска срока обращения в суд, исковые требования могут быть удовлетворены.

Следовательно, если работник сам подаст исковое заявление, то вопрос пропуска срока обращения в суд и его причин даже не будет 
рассмотрен, если об этом не заявит ответчик. А если предписание, выданное по истечении установленных ч. 1 ст. 39 ТК РФ сроков, обжалуется работодателем в суд, то оно будет отменено, и, следовательно, нарушенные права работника не будут восстановлены даже при привлечении работодателя к административной ответственности.

Таким образом, применение судами сроков, установленных ч. 1 ст. 392 ТК РФ (которая называется «Сроки обращения в суд за разрешением индивидуального трудового спора»), к правоотношениям, не связанным с разрешением индивидуальных трудовых споров в судах по искам работников, и отсутствие сроков для обращения в государственные органы за восстановлением нарушенных трудовых прав, к сожалению, препятствуют восстановлению прав работников.

Другая сторона проблемы сокращенных сроков обращения в суд для работников заключается в том, что некоторые работники, зная о сроках обращения в суд, за защитой своих нарушенных прав обращаются в последние дни установленного срока с целью получения с работодателя компенсации морального вреда и материального ущерба в большем размере.

Так, П., будучи уволенным из ООО «С», через две недели после получения трудовой книжки обратился в медицинские учреждения за медпомощью. И через несколько дней после выздоровления отправил исковое заявление в суд почтой. Таким образом, по возможности продлив себе месячный срок для обращения в суд, гражданин П. увеличил и время вынужденных прогулов, т.е. получит больший размер компенсации причиненного незаконным увольнением материального ущерба, чем если бы он добросовестно обратился сразу в суд после получения трудовой книжки.

Таким образом, некоторые «профессионалы» злоупотребляют своим правом на защиту, в результате чего нарушается справедливый баланс прав сторон трудовых правоотношений.

Несмотря на многочисленные обращения граждан в Конституционный суд РФ с заявлениями о признании не соответствующей Конституции РФ ч. 1 ст. 392 Трудового кодекса РФ, позиция законодателя, как и судей Конституционного суда России, остается неизменной, и действующие сроки признаны направленными на соблюдение баланса интересов работника и работодателя. Однако в законодательстве не установлены сроки для обращения в надзорные органы, поэтому, пожалуй, следует либо закрепить сроки работникам для обращения в надзорные органы с заявлениями о нарушении их трудовых прав, либо увеличить срок для обращения в суд. Увеличение срока необходимо на несколько месяцев, с учетом времени, установленного для рассмотрения заявлений работников (максимум 60 дней).

Весной 2013 г. в Государственную думу Федерального собрания РФ внесен законопроект об увеличении сроков обращения в суд за разрешением трудовых споров, согласно которому срок для обращения работника в суд за разрешением индивидуального трудового спора увеличивается с трех до шести месяцев со дня, когда он узнал или должен был узнать о нарушении своего права, а по спорам об увольнении - с одного до трех месяцев со дня вручения ему копии приказа об увольнении либо со дня выдачи трудовой книжки. Авторы законопроекта в пояснительной записке отмечают, что «процесс переписки с органом власти может занять не менее трех-четырех месяцев, что уже превышает установленный в настоящее время ТК РФ общий срок для обращения в суд по трудовым спорам. Таким образом, если государственный инспектор труда либо прокурор не восстановят нарушенное право административно-правовым способом, то работник будет поставлен перед фактом пропуска установленного срока для обращения в суд» [4].

\section{Выводы}

Право на труд в современной России нуждается в защите как органами надзора, так и судебными органами. В действующем законодательстве закреплен достаточно широкий круг полномочий должностных лиц федеральных органов государственного надзора за соблюдением трудового законодательства. Однако, к сожалению, в силу различных обстоятельств государственные инспекторы труда не всегда эффективно используют предоставленные полномочия, закрепленные в рамках института надзора за соблюдением законодательства о труде. При этом в реализации надзорных полномочий Гострудинспекций особая роль отводится защите нарушенных трудовых прав конкретных работников по их обращениям, что подчеркивает ее значение как самостоятельного многоаспектного вида надзорной деятельности Федеральной службы по труду и занятости.

В целях уменьшения препятствий работникам к восстановлению прав работников через суд возможно увеличить сроки обращения в суд по трудовым спорам и установить конкретные сроки обращения в надзорные органы с заявлениями о нарушении своих трудовых прав. 


\section{Список литературы}

1. Трудовой кодекс РФ (ТК РФ) от 30 декабря 2001 г. № 197-ФЗ. Гл. 61. Рассмотрение и разрешение индивидуальных трудовых споров // Собр. законодательства Рос. Федерации. 2002. № 1 (ч. 1), ст. 3.

2. О порядке рассмотрения обращений граждан Российской Федерации : федер. закон от 02 мая 2006 г. № 59-Ф3 (ред. от 07 мая 2013 г.) // Собр. зако- нодательства Рос. Федерации. 2006. № 19, ст. 2060.

3. Постановление Пленума Верховного Суда РФ от 17 марта 2004 г. № 2 «О применении судами Российской Федерации Трудового кодекса Российской Федерации» // Бюллетень Верховного Суда РФ. 2007. № 3 .

4. Законопроект о внесении изменений в ст. 392 Трудового кодекса РФ. URL: http://www.garant.ru/news/ navigator/2013/05/ (дата обращения: 15.05.2013).

\title{
Terms Appeal to the Court: Obstacles to the Protection of Employee or a Way to Fight the Abuse of Rights
}

\author{
O. N. Kurenkova \\ Saratov State University, \\ 83, Astrakhanskaya, Saratov, 410012, Russia \\ E-mail: olga-git64@mail.ru
}

Introduction. The article devoted to the urgent and important issue for modern Russia abbreviated terms apply for the protection of workers' rights. Objective. The main objective of this paper is to analyze the practical situations where a shorter period, prevented workers to protect their rights and situations where employees have abused their right to go to court and did it on the last day of the deadline. Also the aim is to analyze the problems of protection of workers' rights oversight bodies subject to broad interpretation jurisprudence maturities in court. Results. The author consistently discussed various practical situations use abbreviated terms recourse for workers with formal-logical method by studying the practice of the State Labour Inspectorate and the courts of the Saratov region investigated the data situation and draw some conclusions on the protection of workers' rights. Besides concluded the need to improve labor legislation. Conclusions. Author draws conclusions about the state policy and oversight of the positive role of the judiciary as well as pre-trial protection of workers' rights. The paper also emphasizes the adequacy and effectiveness of powers set out under the supervision of the Institute of compliance with labor legislation. In the implementation of supervisory powers, the State Labour Inspectorate specific role for the protection of labor rights violations of individual employees on their applications that emphasizes its importance as a form of self multidimensional oversight of the Federal Service for Labour and Employment.

Key words: labour legislation, Labour code, timing of going to court, State Labour Inspectorate.

\section{References}

1. Trudovoy kodeks RF (TK RF) ot 30 dekabrya 2001 g. № 197-FZ. Glava 61. Rassmotrenie i razreshenie individualnyih trudovyih sporov [The Labour code of the Russian Federation. Chapter 61. Consideration and resolution of individual labor disputes]. Sobranie zakonodatelstva Rossiyskoy Federacii [Collection of legislation of the Russian Federation], 2002, no. 1 (part 1), article 3 (in Russian).

2. O poryadke rassmotreniya obrascheniy grazhdan Rossiyskoy Federatsii: federalnyiy zakon ot 02 maya 2006 № 59-FZ (red. ot 07 maya 2013) [On the order of consideration of references of citizens of the Russian Federation: Federal law dated 02 May 2006, № 59-FZ].
Sobranie zakonodatelstva Rossiyskoy Federacii [Collection of legislation of the Russian Federation], 2006, no. 19, article 2060 (in Russian).

3. Postanovlenie Plenuma Verhovnogo Suda RF ot 17 marta 2004 g. № 2 «O primenenii sudami Rossijskoj Federacii Trudovogo kodeksa Rossijskoj Federacii» [Resolution of the Plenum of the Supreme Court of the Russian Federation of 17 March 2004, № 2]. Byulleten Verhovnogo Suda RF [Bulletin of the Supreme Court of the Russian Federation], 2007, no. 3 (in Russian).

4. Zakonoproekt o vnesenii izmeneniy v st. 392 Trudovogo kodeksa $R F$ (The draft law on introducing changes in article 392 of the Labour code of the Russian Federation). Available at: http://www.garant.ru/news/ navigator/2013/05/ (accessed 15 May 2013). 